\title{
Physico-Chemical Properties of Biscuits Influenced by Different Ratios of Hydrogenated Fat (vanaspati) and Peanut Butter
}

\author{
Lalita Prakash Masih $^{1 *}$, Chitra Sonkar ${ }^{1}$, Suryendra Singh ${ }^{2}$ and Rashmi Chauhan ${ }^{1}$ \\ ${ }^{1}$ Sam Higginbottom University of Agriculture, Technology and Sciences, \\ Allahabad-211007, U.P., India \\ ${ }^{2}$ Guru Angad Dev Veterinary and Animal Sciences University, Ludhiana-141004, Punjab, India \\ *Corresponding author
}

\section{A B S T R A C T}

Keywords

Biscuit, Vanaspati: peanut butter ratios, Sensory evaluation.

Article Info

Accepted:

15 October 2017

Available Online:

10 December 2017
Biscuits prepared with different ratios of hydrogenated fat (vanaspati) and peanut (Arachis hypogaea L.) butter (PB) i.e. (50:00, 40:10, 30:20, 25:25) were evaluated for their physico-chemical properties. Diameter was maximum in biscuits ( $100 \%$ vanaspati), which decreased with increasing proportion of $\mathrm{PB}$. Fat content showed a decreasing trend upon increasing proportion of $\mathrm{PB}$ and was lowest in biscuits (50\% PB). Overall sensory parameters of biscuits improved when $50 \%$ vanaspati replaced by $\mathrm{PB}$ in the standard biscuits recipe. Biscuits prepared with $50 \%$ incorporation of PB had better physico-chemical properties and also a greater overall acceptability.

\section{Introduction}

The term biscuit was derived from the Latin word biscoctus, meaning twice cooked (Macrace et al., 1993). Biscuits are popular foodstuff, consumed by a large number of people today, due to their pleasant taste, prolonged shelf life and easy availability at fairly low cost (Gandhi et al., 2001). Fat is necessary part of diet and it imparts flavor, texture and appearance of the baked product (Pyler, 1988). On the other hand, excess intake of fat in diet may lead to higher risk of diseases like obesity, coronary heart disease and cancer (Akoh, 1998). As biscuits generally have higher fat content, it becomes difficult to prepare biscuits by reducing fat contents in their formulation to lower the risk of such diseases. To reduce the quantity of fat in bakery products fat replacers like peanut butter are used (Sanchez et al., 1995). Peanut is an important legume which has attracted researchers in recent times (Azeket et al., 2005), food having peanut are highly accepted by consumers because of their divine flavour. Peanut butter is a dispersion of peanut oil in peanut solids which results, when roasted peanuts are ground. Peanut butter is a good source of protein and fiber, and low in fat. It is continually applied for the preparation of low calorie improved food products (Woodroof, 1983). The confectionery 
formulations contain hydrogenated fat (vanaspati), which lowers the nutritional value due to presence of large amount of saturated fatty acids (SFA). The biscuits can be used as a source of desirable and essential fatty acid supplementation by utilizing part of peanut butter in place of vanaspati (Gajera et $a l ., 2010)$. Keeping in view all the above facts this research was designed to study the effect of incorporation of peanut butter on physicochemical and sensory properties of biscuits.

\section{Materials and Methods}

\section{Materials}

Refined wheat flour, sugar, hydrogenated fat (vanaspati), peanut (Arachis hypogaea L.) butter (PB), eggs and baking powder were procured from local market of Allahabad and experiment was conducted in the Department of Food Process Engineering, Vaugh Institute of Agricultural Engineering and Technology (SHUATS), Allahabad (Uttar Pradesh) India.

\section{Biscuits preparation}

The biscuits were prepared as per standard recipe (AACC, 2000) the process flow chart of biscuits is given below: The treatment plan used in the preparation of biscuits is given in Table 1.

\section{Methods}

\section{Physical analysis}

The diameter and thickness were measured using Vernier caliper at two and four different places, respectively in each biscuit and the average value was calculated. The average of 6 biscuits was recorded for each batch. Spread ratio was calculated by dividing the average value of diameter by average value of thickness of biscuits according to AACC (2000).
Av. Diameter of biscuits

$$
\begin{array}{r}
\text { Spread ratio }=\text {------------------------ } \\
\text { Av. Thickness of biscuits }
\end{array}
$$

\section{Chemical analysis}

The proximate analysis i.e. moisture, crude fat and ash contents of biscuits were determined as per (AACC, 2000).

Moisture content of biscuits was measured by the hot air oven (Scientronic Instruments, New Delhi) method. 5gm of the sample which has been thoroughly grounded and uniformly mixed was weighed in the dry dish.

After removing the lid of the dish it was heated in an oven at $130^{\circ} \mathrm{C}$ for 2 hour. After 2 hours the dish was removed from desiccator and allowed to cool and weighed. Again the dish was kept in the oven for another 1 hour and was cooled and weighed again. The process was repeated until change in weight between two successive observations could not exceed $1 \mathrm{mg}$. The difference in weights was determined for the determination of the moisture per cent by using following formula:

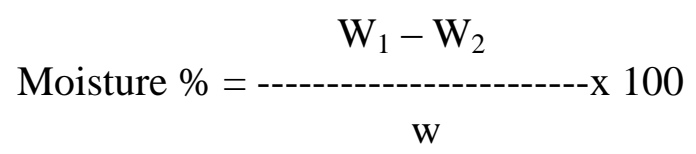

Where,

$\mathrm{W}_{1}=$ Weight in $\mathrm{gm}$ of the dish with the material before drying,

$\mathrm{W}_{2}=$ Weight in gm of the dish with the material after drying and

$\mathrm{W}=\mathrm{Weight}$ in gm of the empty dish

The crude fat is extracted by using Soxhlet apparatus (EIE Instruments Pvt. Ltd., Ahmedabad). The fat was calculated by the following formula: 
(Weight of flask + oil) - (Weight of flask) $\%$ Fat $=$ $\mathrm{x} 100$

Weight of sample

The ash content was measured using muffle furnace. $5 \mathrm{gm}$ of the ground sample was weighed into a silica dish. The material was kept at $550^{\circ} \mathrm{C}$ for 4 hours in a muffle furnace (Meta Instruments, Mumbai). The dish was cooled and weighed. The process was repeated till constant weight was obtained. The total ash content was calculated by difference in weights and was expressed as percent.

$$
\% \text { Ash }=\frac{\text { Weight of ash }}{\text { Weight of the sample }}
$$

\section{Sensory evaluation}

The samples were subjected to sensory evaluation to determine consumer preferences for colour, taste, aroma, flavour and overall acceptability (OAA) by the method described by (Rangana, 2008). A panel of 9 judges was involved in the sensory evaluation exercise. The samples were offered in coded in identical transparent polyethylene bags and were tested individually.

The order of presentation of samples was completely randomized. The panelists rinsed their mouth thoroughly with water after testing each sample and waited for a minute before proceeding to test the next sample. The sensory evaluation was based on a 9-point hedonic scale, where (9) represented "like very much" and (1) is "disliked very much".

\section{Statistical analysis}

The analytical data of samples with equal number of replications (nos.3) for individual parameters were subjected to analysis of variance of completely randomised design
(CRD) following the procedure described by (IASRI, 2011).

\section{Results and Discussion}

\section{Effect of peanut butter incorporation on physical properties of biscuits}

Significant $(\mathrm{P} \leq 0.05)$ variations were recorded among biscuits prepared with different ratios of vanaspati and peanut butter with respect to diameter and thickness.

The minimum diameter and maximum thickness were recorded in treatment $T_{3}$ $(25: 25)$ in which $50 \%$ quantity of vanaspati was replaced by PB (Table 2). These changes in diameter and thickness are reflected in their spread ratio which decreased for increasing levels of PB. Spread ratio is considered most important quality parameter of biscuits as it correlates with texture and overall mouth feel of the biscuits (Bose et al., 2010). Two main factors affect the spread ratio: expansion of dough by leavening and gravitational flow as the thickness of the biscuits prepared with PB were higher than prepared with $100 \%$ vanaspati $\left(\mathrm{T}_{0}\right)$ biscuits. Therefore the reduced spread-ratios of PB biscuits can be attributed to $\mathrm{PB}$ containing more water absorbing constituents like protein and fibre. Several reports (Patel et al., 1996; Hooda et al., 2005) showed that reduced spread ratio was observed when wheat flour was substituted by high protein and /high fibre ingredients. These constituents form aggregates with available hydrophilic sites thus reducing free water in biscuit dough (McWatters, 1978). Rapid partitioning of free water of these hydrophilic sites occurs during dough mixing and increases dough viscosity, thereby limiting biscuit spread. A reduced spread ratio seen in PB biscuits increases their suitability for rotary mould preparation in which a lower spread is desirable to keep the embossing intact (Hooda et al., 2005). 
Effect of peanut butter incorporation on chemical properties of biscuits

\section{Fat content}

Fat content was higher $(21.10 \%)$ in treatment $\mathrm{T}_{0}$ (50: 00) which gradually decreased with increasing proportion of $\mathrm{PB}$, which was statistically different $(\mathrm{P}<0.05)$ from other treatments (Table 3 ). The lowest fat content $(16.20 \%)$ was recorded in treatment $\mathrm{T}_{3}$.

This was due to the high content of SFA in vanaspati and low content in PB. These findings are in accordance with the findings of (Wekwete et al., 2009), who observed that peanut butter, had lower fat content than hydrogenated vegetable shortening. Hence, with increasing levels of peanut butter as a substitute for hydrogenated vegetable shortening the fat content of biscuit decreased, which is good for health. There was a significant negative correlation between PB and fat content (Fig. 1). The fat content decreased by 0.18 per cent with unit increase in PB. At $25 \mathrm{gm}$ of PB, the fat content was minimum, which could be considered as the optimum level of PB for biscuit making.

\section{Moisture and ash content}

There was a change in moisture and ash content in biscuits with the incorporation of peanut butter (Table 3). The highest moisture and ash content (3.30 and $2.41 \%$ respectively) were recorded in treatment $T_{1}$, which was statistically different with all the other treatments and showed a decreased trend among the treatments, but, on an average the content of both was higher than the control treatment $\mathrm{T}_{0}$. The increase in moisture content might be attributed to higher amount of fiber in peanut butter and fiber has strong affinity for water and products containing fiber. (Yadav et al., 2012) also reported that with the addition of partially de-oiled peanut meal flour ash content of biscuits increased slightly.

Table.1 Treatment plan: Hydrogenated fat (vanaspati) to peanut butter ratios in standard recipe of biscuits

\begin{tabular}{|l|c|}
\hline Treatment & Hydrogenated fat (vanaspati): peanut butter ratios \\
\hline$T_{0}$ & 50:00 (100\% Vanaspati) \\
\hline$T_{1}$ & $40: 10$ \\
\hline$T_{2}$ & $30: 20$ \\
\hline$T_{3}$ & $25: 25$ \\
\hline
\end{tabular}

Table.2 Effect of hydrogenated fat (vanaspati) substitution with peanut butter on physical characteristics of biscuits

\begin{tabular}{lccc}
\hline Treatment & Diameter $(\mathrm{cm})$ & Thickness $(\mathrm{cm})$ & Spread ratio \\
\hline $\mathrm{T}_{0}$ & $4.51 \mathrm{a}$ & $0.71 \mathrm{a}$ & $6.35 \mathrm{a}$ \\
$\mathrm{T}_{1}$ & $4.01 \mathrm{~b}$ & $0.72 \mathrm{a}$ & $5.56 \mathrm{~b}$ \\
$\mathrm{~T}_{2}$ & $4.02 \mathrm{~b}$ & $0.71 \mathrm{a}$ & $5.66 \mathrm{~b}$ \\
$\mathrm{~T}_{3}$ & $3.53 \mathrm{c}$ & $0.90 \mathrm{a}$ & $3.92 \mathrm{c}$ \\
\hline $\mathrm{CV}(\%)$ & 10.05 & 12.29 & 19.17 \\
\hline
\end{tabular}


Table.3 Effect of hydrogenated fat (vanaspati) substitution with peanut butter on chemical characteristics of biscuits

\begin{tabular}{lccc}
\hline Treatment & Fat content $(\%)$ & Moisture content $(\%)$ & Ash content $(\%)$ \\
\hline $\mathrm{T}_{0}$ & $21.10 \mathrm{a}$ & $3.12 \mathrm{ab}$ & $1.82 \mathrm{~d}$ \\
$\mathrm{~T}_{1}$ & $18.50 \mathrm{~b}$ & $3.30 \mathrm{a}$ & $2.41 \mathrm{a}$ \\
$\mathrm{T}_{2}$ & $17.36 \mathrm{c}$ & $2.94 \mathrm{c}$ & $2.21 \mathrm{~b}$ \\
$\mathrm{~T}_{3}$ & $16.20 \mathrm{~d}$ & $2.80 \mathrm{~d}$ & $1.89 \mathrm{c}$ \\
\hline $\mathrm{CV}(\%)$ & 2.98 & 6.18 & 11.50 \\
\hline
\end{tabular}

\section{Biscuits preparation}

Mixing the peanut butter, hydrogenated fat and sugar

Blending of wheat flour and baking powder

(At slow speed for 12 minutes and mixed with other ingredients at high speed for 20 minutes)

Dough formed into a sheet

$\downarrow$

Cut the dough into small size pieces of required size

(Round shaped)

Place in baking tray $(1 \mathrm{~cm}$ apart)

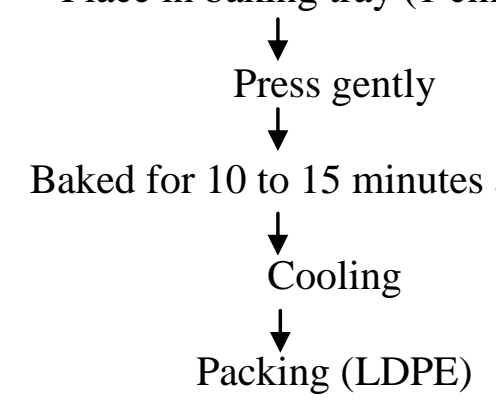

Fig.1 Relationship between peanut butter and fat content

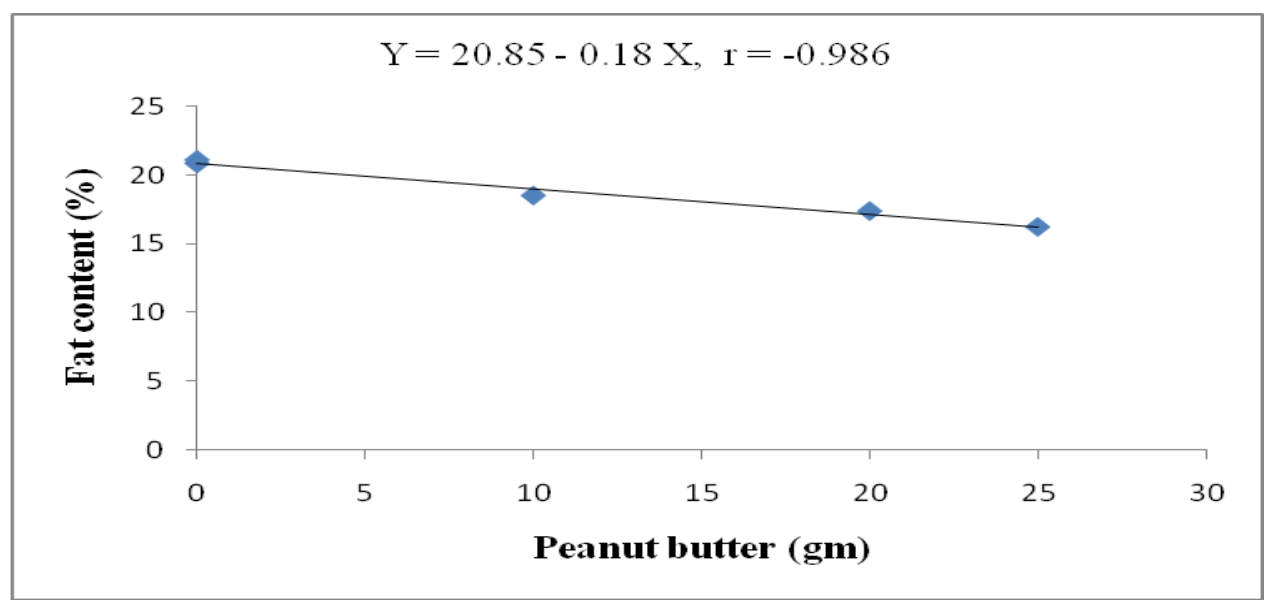


Fig.2 Effect of hydrogenated fat (vanaspati) substitution with peanut butter on sensory parameters

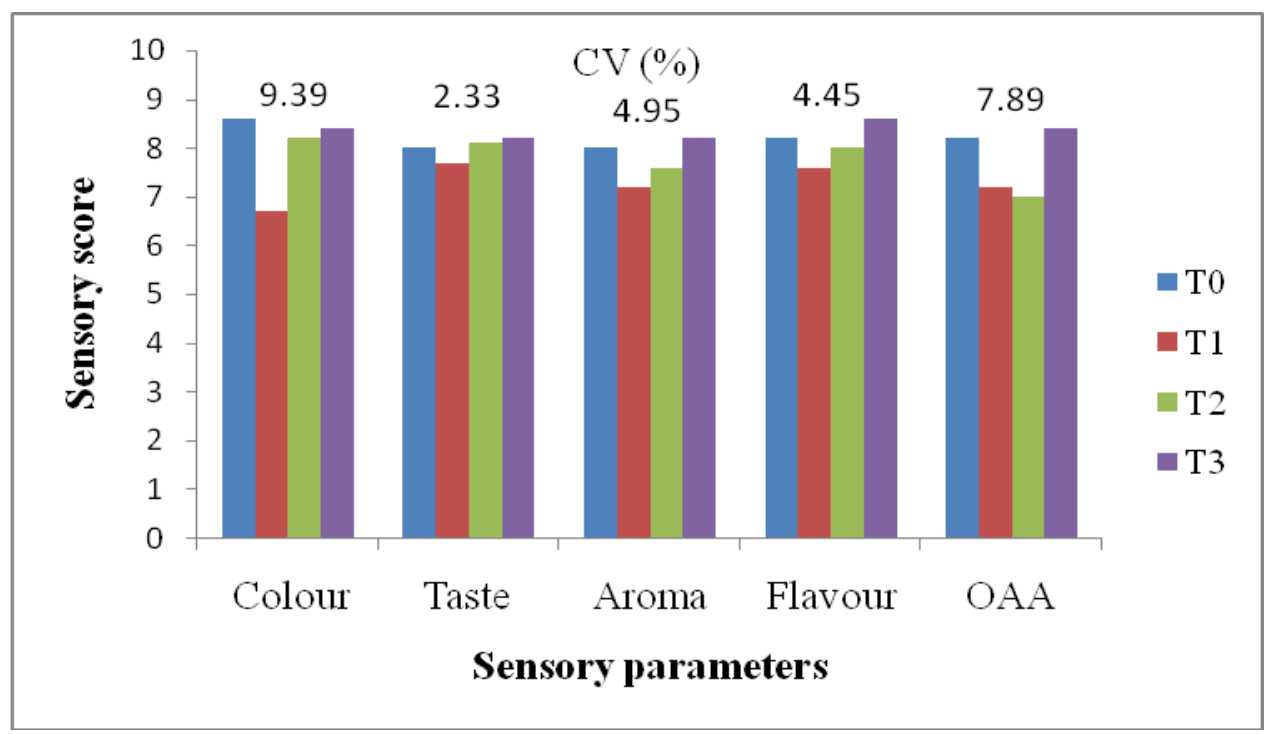

Effect of peanut butter incorporation on organoleptic characteristics of biscuits

Significant $(P \leq 0.05)$ variations were found among biscuits prepared with different ratios of vanaspati and peanut butter with respect to their color, taste, aroma, flavour and overall acceptability (Fig. 2).

\section{Color}

The results showed that the biscuits became darker with incorporation of peanut butter. Highest score (8.3) was recorded for $\mathrm{T}_{\mathbf{3}}$ among the treatments. Lowest score (6.70) was recorded in $\mathrm{T}_{1}$ where $80 \%$ vanaspati and $20 \%$ peanut butter were used as raw materials to prepare biscuits. The reason of darker color of the biscuits might be due to high level of protein present in the peanut butter. The colour development is contributed by the maillard reaction i.e. reaction between sugars and proteins of product that results in brown colour (Singh et al., 1993). Other factors that may be responsible for colour development are time and temperature of baking, composition, humidity in oven etc. (Lingnert, 1990) and (Wade, 1988).

\section{Flavour and aroma}

Flavour and aroma of biscuits progressively increased with increasing levels of peanut butter (Fig. 2). The highest score was recorded for $\mathrm{T}_{3}$, while lowest score was recorded for treatment $T_{1}$. Similar results were observed by (Yadav et al., 2012) who found that the typical peanut flavour and aroma was highly acceptable by the panel members.

\section{Over All Acceptability (OAA)}

Biscuits' acceptability was in acceptable range (Fig. 2) with maximum score of (8.40) for biscuits prepared with 50\% PB in place of hydrogenated fat (vanaspati) $\mathrm{T}_{3}$ while minimum score (7.00) for biscuits prepared with $40 \%$ PB in place of vanaspati $\left(\mathrm{T}_{2}\right)$.

(Adair et al., 2001) reported that product acceptability was declined when fat was substituted by more than $50 \%$ with mung bean paste. (Shrestha et al., 2002) found greater acceptance of kinema- supplemented (which was prepared from natural fermentation of soybean) biscuits in 
comparison with full-fat soyabean flour supplemented biscuits.

It is concluded that biscuits prepared with the incorporation of PB to reduce the quantity of vanaspati had shown maximum overall acceptability, this substitution of $\mathrm{PB}$ for vanaspati of the biscuits also decreased spread ratio and fat content. The most acceptable formulation was vanaspati: peanut butter (25:25). PB also imparted better taste, aroma and flavour to biscuits.

\section{References}

AACC. 2000. Approved laboratory methods, $9^{\text {th }}$ ed. American Association of Cereal Chemists. Minnesota, USA.

Adair, M., Knight, S. and Gates, G. 2001. Acceptability of peanut butter cookies prepared using mungbean paste as a fat ingredient substitute. $J$ Am Dietetic Assoc. 101: 467-469.

Akoh, K.1998. Scientific status summary: Fat replacers. Food Technology Magazine. 52(3): 47-53.

Azeket, M. A., Fretzdorft, B., Buening, P. H., Holzapfel, W. and Betsche, T. 2005. Nutritional value of African yam bean (Sphenostylis stenocarpa L.): improvement by lactic acid fermentation. Journal of Food Science and Agriculture. 85(6): 963-970.

Banureka, V. D. and Mahendran, T. 2009. Formulation of wheat-soybean biscuits and their qualiy characteristics. Tropical Agricultural Research and Extension. 12(2): 62-66.

Bose, D. and Shams-Ud-Din, S. 2010. The effect of chickpea (Cicer arietinim) husk on the properties of cracker biscuits. J Bangladesh Agric Univ. 8(1):147-152.

Gajera, H. P., Kapopara, M. B. and Patel, V. H. 2010. Application of peanut butter to improve fatty acid composition of biscuits. J Food Sci Technol. 47(3): 285-289.

Gandhi, A. P., Kotwaliwale, N., Kawalkar, J. D., Srivastava, C. V., Parihar, S. and Raghu, N. P. 2001. Effect of incorporation of defatted soy flour on the quality sweet biscuits. Journal of Food Science and Technology. 38: 502503.

Hooda, J. and Jood, S. 2005. Organoleptic and nutritional evaluation of wheat biscuits supplemented with untreated and treated fenugreek flour. Food Chem. 90: 427-435.

Indian Agricultural Statistics Research Institute (ICAR), New Delhi 110 012, India. www.iasri.res.in/design (accessed lastly on 01/ 05/ 2011). 01/ 01/ 20011 with the actual date of accession.

Lingnert, H. 1990. Development of the maillard reaction during food processing, In: P. A. Finot, Ed., Maillard Re-action in Food Processing, Human Nutrition and Physiology. 171 pp.

Macrae, R. R., Robinson, K. and Sacdler, M. J. 1993. Encyclopedia of Food Science. Food technology and Nutrition, 345 pp. London: Academic Press Harcourt Brace Jovanovich Publications.

Mcwatters, K. H. 1978. Cookie baking properties of defatted peanut, soybean, and field pea flours. Cereal Chem. 55: 853-863.

Patel, M. M., Rao, G.V. 1996. Effect of untreated, roasted, and sprouted black gram (Phaseolus mungo) flours on the physico-chemical and biscuit (cookie) making characteristics of soft wheat flour. J Cereal Sci. 22: 285-291.

Pyler, E. J. 1988. Baking science and technology. $3^{\text {rd }}$ edition. pp. 854-857. USA: Sosland publishing.

Ranganna, S. 2008. Hand book of analysis and quality control for fruit and vegetable products, Tata McGraw-Hill 
publishing company Ltd., New Delhi, $2^{\text {nd }} \mathrm{Ed}$.

Sanchez, C., Klopfenstein, C. F. and Walker, G. E. 1995. Use of carbohydrate-based fat substitute and emulsifying agents in reduced fat short bread cookies. Cereal Chemistry. 72(1): 25-29.

Shrestha, A.K., Noomhorm, A., Noomhorm Athapol. 2002. Comparison of physicochemical properties of biscuits supplemented with soy and kinema fours. Int J Food Sci Technol. 37: 361368.

Singh, B., Bajaj, M., Kaur, A., Sharma, S. and Sidhu, J. S. 1993. Studies on the development of high protein biscuits from Composite flour," Plant Foods for Human Nutrition. 43(2): 181-189.

Wade, P. 1988. Biscuits, Cookies and Crackers: Vol. 1," Essex: Elsevier
Applied Science Publishers Ltd., London.

Wekwete, B. S. and Navder, K. P. 2009. Effects of avocado fruit puree and oatrim as fat replacers on the physical, textural and sensory properties of oatmeal cookies. Journal of Food Quality. 31(2): 31- 144.

Woodroof, J.G. 1983. Peanut butter. In: Peanuts: Production, processing and products, AVI Publishing Co, Inc, $3^{\text {rd }}$ ed., West port, Connecticut, 127pp.

Yadav, D. N., Thakur, Neharika and Sunooj, K. V. 2012. Effect of partially deoiled peanut meal flour (DPMF) on the nutritional, texrtural, organoleptic and phyioco chemical properties of biscuits. Food and Nutrition Sciences. 3: 471476.

\section{How to cite this article:}

Lalita Prakash Masih, Chitra Sonkar, Suryendra Singh and Rashmi Chauhan. 2017. PhysicoChemical Properties of Biscuits Influenced by Different Ratios of Hydrogenated Fat (vanaspati) and Peanut Butter. Int.J.Curr.Microbiol.App.Sci. 6(12): 1804-1811. doi: https://doi.org/10.20546/ijcmas.2017.612.204 